\section{Thick as thieves - the Norwegian medical association attempts to stifle ethical debate}

\author{
Søren Holm
}

In January 2006, one of the major cases of scientific fraud in recent years broke in the media. It was discovered that the Norwegian researcher John Sudbø had falsified the complete set of data on which an article published in the Lancet in 2005 had been based. ${ }^{1}$ The article had 14 authors, and Professor Jan Helge Solbakk, Professor of Medical Ethics at the University of Oslo, was quoted in Norwegian media as saying that "... also the 13 other co-authors in the research scandal have muck on their hands..." and: "That none of the 13 has discovered what took place shows clearly that they have not been close to fulfilling the criteria for being co-authors."

One of the co-authors complained to the Norwegian Medical Association's (NMA's) Council for Professional Ethics about these comments, and in June 2007, the Council decided that Solbakk's comments constituted a breach of Section II.5 of the NMA's Ethical Rules for Medical Doctors-which states that "Public and other debate between colleagues in medical and health policy questions must be kept at a matter-of-fact level"-because Solbakk had been "unnecessarily judgemental". 34

This decision is astonishing, perverse and immensely problematic for the future of open debate about one of the major issues in science ethics-that is, the

Correspondence to: Søren Holm, Cardiff Law School, Cardiff University, Law Building, Museum Avenue, Cardiff CF103AX, UK; holms@cardiff.ac.uk question of the relationship between problematic co-authorship practices and other types of scientific fraud.

What is the justification for calling this decision astonishing, perverse and immensely problematic? First, Solbakk was almost certainly correct in his assessment of the prima facie state of scientific cleanliness of the co-authors. They might well be able to wash away this stain by showing how they diligently fulfilled all their obligations as collaborators and coauthors during the process leading up to the fraudulent publication and still did the Medical Faculty of the University of Oslo stated using another Norwegian proverb, "If you hug a chimney sweep you will get black." (For some strange reason, no complaint was put forward against him!)

Second, the Council did not try to establish whether Solbakk was actually right, or whether some or all of the 13 coauthors, including the complainant, had or had not fulfilled standard co-authorship criteria. This is still an open question. The official commission investigating the Sudbø case decided that it did not have the capacity to investigate all of the $60 \mathrm{co}$ authors that had collaborated with Sudbo on the 13 papers that were eventually found to be fraudulent. In the end, it extensively investigated only Sudbø's former boss and doctoral supervisor. ${ }^{5}$

Third, if the standard that the Council applied was applied across the field of science and medical ethics and no one was allowed to comment trenchantly before a not discover the fraud, but as the dean of case was thoroughly investigated, it would completely stifle public debate about ethics. In the Sudbø case, it would mean that it would still be impossible to discuss the evident co-authorship problems. As they are interpreted by the Council, the Rules of Professional Ethics of the NMA require self-censorship in debate about ethics, and the Council evidently stands ready to censure those who are not willing to censor themselves.

It thus seems that open debate about medical ethics issues in Norway can in the future be conducted only by those who are outside the imagined jurisdiction of the NMA's Council of Profesional Ethics or who are willing to ignore its rulings.

It is often repeated that the professions are a conspiracy against the laity and that doctors, especially, are as thick as thieves. With their decision, the Council for Professional Ethics of the NMA has unfortunately shown that these allegations are not totally without justification. The decision may also have shown that at least some doctors are "thick" in the more modern colloquial sense of that word. It is hard to see how any reasonable person could have believed that this decision was the right one to make.

Competing interests: Søren Holm holds a part-time chair at the University of Oslo and is a colleague of Jan Helge Solbakk.

Received 24 September 2007

Accepted 27 September 2007

J Med Ethics 2008;34:1. doi:10.1136/jme.2007.023259

\section{REFERENCES}

1. Sudbø J, Lee JJ, Lippman SM, et al. Non-steroidal anti-inflammatory drugs and the risk of oral cancer: a nested case-control study. Lancet 2005;366:1359-66.

2. Grov Ukultur. TV2 Nettavisen 15.1.2006.

3. Den norske legeforening. Etiske regler for leger. http://www.legeforeningen.no/index.gan?id = 485 (accessed 19 November 2007)

4. Den norske legeforenings råd for legeetik. Brev til Jon Mork 27 Jun 2007.

5. Radiumhospitalet HF og Universitetet i Oslo Rapport fra granskningskommisjon oppnevnt av Rikshospitalet -18. januar 2006. Oslo: Rikshospitalet, 2006. 


\section{JME}

\section{Thick as thieves - the Norwegian medical association attempts to stifle ethical debate}

J Med Ethics 2008 34: 1

doi: 10.1136/jme.2007.023259

Updated information and services can be found at:

http://jme.bmj.com/content/34/1/1.full.html

These include:

References This article cites 1 articles

http://jme.bmj.com/content/34/1/1.full.html\#ref-list-1

Article cited in:

http://jme.bmj.com/content/34/1/1.full.html\#related-urls

Email alerting Receive free email alerts when new articles cite this article. Sign up in service the box at the top right corner of the online article.

Notes

To request permissions go to:

http://group.bmj.com/group/rights-licensing/permissions

To order reprints go to:

http://journals.bmj.com/cgi/reprintform

To subscribe to BMJ go to:

http://group.bmj.com/subscribe/ 